Віталій Саган

старший викладач кафедри логістики

Національної академії Державної прикордонної служби України імені Богдана

Хмельницького, м. Хмельницький

ORCID ID 0000-0003-1042-8353

DOI: $10.33099 / 2617-1775 / 2021-01 / 289-304$

\title{
КРИТЕРІЇ, ПОКАЗНИКИ ТА РІВНІ СФОРМОВАНОСТІ ПРОФЕСІЙНОӤ ГОТОВНОСТІ МАЙБУТНІХ ОФІЦЕРІВ ДО ВЕДЕННЯ ВІЙСЬКОВОГО (КОРАБЕЛЬНОГО) ГОСПОДАРСТВА У ПІДРОЗДІЛАХ ДЕРЖАВНОЇ ПРИКОРДОННОЇ СЛУЖБИ УКРАЇНИ
}

У статті здійснено аналіз наукової літератури й висвітлено погляди щзодо вибору критеріїв, показників та рівнів сформованості професійної готовності майбутніх офіиерів до ведення військового (корабельного) господарства у підрозділах Державної прикордонної служби України (далі-ДПСУ).

У прочесі дослідження дійшли висновків, щуо вивчати готовність потрібно відповідно до конкретного виду діяльності, враховуючи загальні, уніфіковані для будь-якої професійної діяльності компоненти та специифічні професійні компоненти готовності, які $\epsilon$ притаманними певному виду діяльності.

Ключові слова: військове (корабельне) господарство, критерії, показники, рівні, професійна готовність.

Всебічний розвиток i вдосконалення військового (корабельного) господарства, впровадження наукової роботи при його організації та веденні, постійне покращення матеріально-побутових умов та задоволення культурних потреб військовослужбовців, економне витрачання матеріальних та грошових коштів, вміле і ефективне використання техніки при виконанні господарських заходів є одним 3 найважливіших завдань командирів, начальників і всього особового складу Державної прикордонної служби України.

Важливим завданням військових закладів вищої освіти України виступає ефективна підготовка висококваліфікованих, конкурентоспроможних фахівців, здатних на високому рівні здійснювати професійну діяльність. Сьогодні система військової освіти вимагає різнопрофільних фахівців, здатних ефективно діяти в різних напрямках та при різних умовах оперативно-службової діяльності. Одним із важливих напрямів професійної готовності майбутніх офіцерів виступає формування їхньої готовності до організації ведення військового (корабельного) господарства у підрозділах ДПСУ.

Для майбутнього офіцера опанування організацією господарської діяльності у підрозділі ДПСУ виступає невичерпним джерелом розвитку відповідальності та активності, готовності підтримати, прийти на допомогу, уміння організувати господарську діяльність; надає можливість отримати нові знання та досвід, що викликають їхній інтерес і сприяють професійному самовизначенню. 
Одним із ефективних організаторів ведення військового (корабельного) господарства у підрозділі ДПСУ може виступати добре підготовлений майбутній офіцер, який володіє спеціальними знання, вміннями та досвідом щодо реалізації відповідного напрямку діяльності. Безумовно тому, є підстави вважати, про потреби у постійному удосконаленні змісту, форм та методів професійної підготовки майбутніх офіцерів до ведення військового (корабельного) господарства у підрозділах ДПСУ. Ефективність такого процесу визначається за спеціальними критеріями, показниками та рівнями сформованості професійної готовності до ведення військового (корабельного) господарства у підрозділах ДПСУ.

Оптимізація організаційно-штатної структури Державної прикордонної служби України призвела до скорочення на відділах прикордонної служби посади заступника начальника відділу прикордонної служби з логістики разом 3 тим залишились поодинокі підрозділи де відповідні посади ще існують.

Поряд із цим наказом Адміністрації Державної прикордонної служби України від 21 грудня 2020 року №134 «Про затвердження Порадника 3 військового (корабельного) господарства Державної прикордонної служби України» визначено, що посадові особи органів та підрозділів Державної прикордонної служби України які здійснюють організацію та ведення військового (корабельного) господарства, відповідають за це господарство та виконують свої обов'язки згідно з вимогами Закону України «Про Статут внутрішньої служби Збройних Сил України».

Для організації ведення військового (корабельного) господарства у самостійному прикордонному підрозділі, що виконує завдання з охорони державного кордону, структурних підрозділах органу охорони кордону військовослужбовцям необхідно володіти необхідними знаннями, вміннями та навичками.

Навчальні плани для реалізації ОПП «252 Безпека державного кордону», «274 Автомобільний транспорт», «053 Психологія», «172 Телекомунікації та радіотехніка», «035 Філологія» набору 2020 року не передбачають навчальних дисциплін, які спроможні забезпечити майбутніх офіцерів необхідними знаннями, вміннями, навичками щодо організації ведення військового (корабельного) господарства у підрозділах ДПСУ.

Аналіз останніх досліджень і публікацій. Критерії, показники та рівні сформованості професійної готовності майбутніх офіцерів були досліджені різними науковцями, наприклад, у роботах Балагур Л.О. «Підготовка майбутніх офіцерів-прикордонників до управління основними підрозділами охорони державного кордону» [1], Войцехівського О.В. «Підготовка майбутніх офіцерів-прикордонників до професійної діяльності в пунктах пропуску через державний кордон» [2], Гащука В.А. «Педагогічні умови деонтологічної підготовки майбутніх офіцерів-прикордонників» [3], Гнидюк О.Я. «Підготовка майбутніх офіцерів-прикордонників до роботи 3 нанесення контрольованих прикордонних районів» [4], Гнидюка О.П. «Педагогічні умови підготовка майбутніх офіцерів-прикордонників до фізичного самовдосконалення» [5], Заболотної О.Р. «Підготовка майбутніх офіцерів-прикордонників до роботи 3 
технічними засобами прикордонного контролю» [6], Чудика А.В. «Підготовка майбутніх офіцерів-прикордонників до застосування спеціальних засобів та заходів фізичного впливу у процесі оперативно-службової діяльності» [7]. Разом з тим критерії, показники та рівні сформованості професійної готовності офіцера-прикордонника до ведення військового (корабельного) господарства у підрозділах Державної прикордонної служби України не досліджувалися.

Мета статті - розробити критерії, показники та рівні сформованості професійної готовності майбутніх офіцерів до ведення військового та корабельного господарства у підрозділах ДПСУ.

Методи дослідження. Для дослідження анонсованої теми використовувалися методи спостереження, соціологічного опитування, тестування, аналізу і синтезу.

Виклад основного матеріалу дослідження. 3 метою виконання одного із завдань наукового дослідження - визначення стану професійної підготовки майбутніх офіцерів до ведення військового (корабельного) господарства у підрозділах Державної прикордонної служби України - у статті висвітлено процес розробки критеріїв, показників досліджуваної властивості особистості та схарактеризовано рівні їі сформованості.

Для визначення критеріїв i показників, за допомогою яких можна всебічно охарактеризувати професійну готовність майбутніх офіцерів до ведення військового (корабельного) господарства у підрозділах Державної прикордонної служби України, було проведено аналіз наукової літератури.

Визначення критеріїв, показників сформованості професійної готовності до різних видів діяльності були предметом уваги багатьох науковців. Результати вивчення напрацювань стосовно цього питання показали, що на сьогодні у педагогічній і психологічній літературі існує декілька поглядів щодо критеріїв оцінювання готовності майбутніх фахівців до професійної діяльності. Але перед тим як розв'язувати анонсоване завдання, вбачаємо за необхідне уточнити сутність понять: «критерій», «показник», «рівень».

С. Карпенчук пропонує таке визначення критерію - це мірило, ознака, на основі якої здійснюється оцінка якої-небудь якості [8, с. 275]. В Українському педагогічному словнику критерій визначено як «засіб переконання, мірило» [9]. У юридичній та психологічній довідковій літературі терміном «критерій» (від грец. kriterion - засіб судження) називають: мірило для визначення, оцінку предмета, явища; ознаку, узяту за основу класифікації; підставу для оцінки, визначення або класифікації чогось; мірило, мірку; стандарт, виходячи з якого можуть прийматися рішення, робитись оцінки або класифікація; рівень досягнень, який визначається метою, ступенем наближення до якої оцінюється прогрес [10].

Термін «показник», за Новим тлумачним словником української мови, визначено як свідчення, доказ, ознака чого-небудь; наочні дані про результати якоїсь роботи, якогось процесу; дані про досягнення чого-небудь [11].

У Короткому тлумачному словнику української мови, Тлумачному словнику української мови визначають рівень як «ступінь, що характеризує якість, висоту, величину розвитку чогось» $[12$, с.231; 13, с.399]. Новий 
тлумачний словник української мови визначає рівень як ступінь якості, величину, досягнуті у чому-небудь; сутність чиєїсь освіти, культури, підготовки [11, с.128].

Процес пошуку й перевірки на практиці системи критеріїв професійної готовності передбачає здійснення аналізу наявних підходів до розуміння їх сутності. Результати цілеспрямованого вивчення проблеми критеріїв сформованості у педагогічних дослідженнях показали наявність декількох основних підходів до їх розуміння.

Так, наприклад, О. Войцехівський, досліджуючи сформованість готовності майбутніх офіцерів-прикордонників до професійної діяльності в пунктах пропуску через державний кордон, пропонує такі критерії: мотиваційно-цільовий, процесуальний, оцінно-результативний. Мотиваційноцільовий компонент зумовлений сформованістю мотивів і цілей; зацікавленістю; наявністю стійкого інтересу до роботи; цілеспрямованим досягненням поставленої мети; самовладанням за будь-яких професійних обставин; здатністю приймати рішення. Процесуальний критерій передбачає уміння і навички забезпечити творчій рівень професійних умінь у реалізації потреб особистості. Оцінно-результативний критерій передбачає оцінку навчальної діяльності курсанта; самооцінку власних досягнень, визначення шляхів удосконалення результатів діяльності. На його думку зміст зазначених критеріїв має забезпечити формування професійної готовності до службової діяльності [2].

О. Гнидюк у своєму дослідженні [5] зазначив, що вибір критеріїв для діагностики готовності до професійної діяльності в основному залежить від необхідності встановити рівень засвоєння знань, сформованості професійних умінь і навичок, а також - від психологічної готовності до здійснення професійних функцій. Автор дійшов висновку, що для встановлення рівня готовності майбутніх офіцерів-прикордонників до роботи 3 населенням контрольованих прикордонних районів потрібно обрати три критерії: когнітивний - який дозволяє встановити рівень знань, необхідних для роботи, розуміння та уявлення про обсяг обов'язків і завдань за цією діяльністю; мотиваційно-изінісний, що застосовується для встановлення рівня мотивації до діяльності, сформованості соціокультурних цінностей і професійних якостей; практичний критерій - 3 метою оцінювання умінь і навичок 3 організації взаємодії з населенням контрольованих прикордонних районів.

У праці О. Заболотної «Підготовка майбутніх офіцерів-прикордонників до роботи з технічними засобами прикордонного контролю» [6] для визначення рівнів сформованості готовності пропонується виділити три критерії: мотиваційний (дає змогу формувати стійкі професійні, пізнавальні інтереси, позитивне ставлення, засвоювати знання, прагнути до саморозвитку в сфері застосування технічних засобів прикордонного контролю); когнітивний (дає уявлення про уміння використовувати можливості технічних засобів прикордонного контролю; повноту й диференційованість знань щодо технічних засобів прикордонного контролю, знань про практику застосування; розуміння власних знань, умінь, необхідних для використання технічних засобів 
прикордонного контролю); діяльнісний критерій (характеризує здатність до самокерування в діяльності з вивчення та застосування технічних засобів, уміння самостійно оволодівати технічними засобами; практичний рівень оволодіння технічними засобами; самоконтроль і корекцію своїх дій під час застосування технічних засобів; самоактуалізацію потенційних можливостей щодо використання технічних засобів прикордонного контролю в професійній діяльності).

А. Чудик під критерієм розуміє стандарт, що дозволяє відокремити та порівняти окремі сторони педагогічного об'єкта - процесу або явища [7]. У своєму дослідженні він дійшов висновків, що 3 урахуванням структури готовності курсантів до застосування спеціальних засобів і заходів фізичного впливу та змісту ії компонентів, особливостей оперативно-службової діяльності (далі - ОСД) офіцерів-прикордонників, для оцінки рівня сформованості їх готовності до застосування спеціальних засобів та заходів фізичного впливу доцільно виокремити такі три критерії: особистісний, що характеризує професійну мотивацію і спрямованість; ставлення до формування готовності до застосування спеціальних засобів; інтерес до проблеми використання спеціальних засобів; визначає особистісні характеристики які сприяють успішному формуванню готовності до застосування спеціальних засобів; когнітивний критерій характеризує сукупність знань про ОСД й про використання спеціальних засобів; діяльнісний критерій характеризує вміння використовувати спеціальні засоби та володіти іншими необхідними навичками.

Проаналізувавши вищенаведені погляди щодо вибору критеріїв, сформованості професійної готовності майбутніх офіцерів, ми дійшли висновків, що вивчати готовність потрібно відповідно до конкретного виду діяльності, враховуючи загальні, уніфіковані для будь-якої професійної діяльності критерії та специфічні професійні критерії готовності, які $\epsilon$ притаманними саме для певного виду діяльності [15].

Усвідомлюючи це, ми пропонуємо для визначення критеріїв, показників та рівнів сформованості професійної готовності майбутніх офіцерів до ведення військового (корабельного) господарства у підрозділах Державної прикордонної служби України виокремити питання, які потребують уваги для формування досліджуваної властивості.

Для вирішення цього завдання було проаналізовано відповідні відомчі документи Державної прикордонної служби України.

У наказі Державної прикордонної служби від 21.12.2020 р. №134 «Про затвердження Порадника 3 військового (корабельного) господарства» [14] зазначено, що військове (корабельне) господарство - це:

сили і засоби, які входять до складу органів (підрозділів) ДПСУ а також передані їм у постійне чи тимчасове користування;

об'єкти матеріально-технічної бази;

матеріальні засоби, що призначені для забезпечення оперативнослужбової діяльності, бойової (професійної) підготовки і роботи з особовим 
складом, побуту, правильної експлуатації, ремонту, зберігання озброєння, військової техніки і майна.

Військове (корабельне) господарство ведеться в органах та підрозділах Державної прикордонної служби.

Органами ДПСУ виступають - загони морської охорони; прикордонні загони; окремі контрольно-пропускні пункти; авіаційні частини; навчальні заклади; науково-дослідні установи; органи забезпечення; підрозділи спеціального призначення, які ведуть господарську діяльність, на які покладено завдання щодо матеріального і технічного забезпечення діяльності органів та їх особового складу.

Підрозділами органу ДПСУ виступають - відділ прикордонної служби, прикордонні комендатури, кораблі, прикордонні застави, які входять до складу органів ДПСУ, беруть участь у веденні господарювання органу та на які покладено завдання щодо матеріально-технічного забезпечення діяльності підрозділів та їх особового складу.

Також у наказі [14] передбачено, що посадові особи, які здійснюють організацію та ведення військового (корабельного) господарства, відповідають за це господарство та виконують свої обов'язки згідно з вимогами Закону України «Про Статут внутрішньої служби Збройних Сил України», інших законів, нормативних актів Кабінету Міністрів України, Міністерства внутрішніх справ України, відповідних Положень за напрямками діяльності.

За результатами проведеного аналізу було з’ясовано, що у навчальних планах для реалізації ОПП «252 Безпека державного кордону», «274 Автомобільний транспорт», «053 Психологія», «172 Телекомунікації та радіотехніка», «035 Філологія» набору 2020 р. та попередніх наборів включно до 2016 року немає навчальних дисциплін, які спроможні забезпечити необхідними знаннями, вміннями, навичками майбутніх офіцерів, щодо організації ведення військового (корабельного) господарства у підрозділах ДПСУ. Докладно перебіг і результати аналізу подано у роботі [16].

Як з’ясувалося, кожна військова частина, підрозділ Державної прикордонної служби України для забезпечення особового складу та виконання завдань постійно отримують від держави значну кількість матеріальних i грошових засобів, а також мають необхідні житлові, службові приміщення та інші об'єкти різного призначення. Усе це становить матеріальну основу військового (корабельного) господарства.

Основними завданнями військового (корабельного) господарства є всебічне та безперебійне забезпечення служби щодо охорони та захисту державного кордону України, бойової підготовленості, побуту особового складу, забезпечення бойової та мобілізаційної готовності військових частин i підрозділів для швидкого переходу їх з мирного у військовий стан.

Організація та ведення військового (корабельного) господарства включає: планування й організацію роботи відділень, служб, відділів, підрозділів та об’ єктів господарського, технічного, медичного, ветеринарного призначення, а також постійного керування і забезпечення контролю за цією роботою; 
витребування, отримання, підвоз, зберігання, видачу і використання матеріальних та грошових засобів;

своєчасне та повне доведення до особового складу визначеного забезпечення, задоволення його матеріально-побутових, культурних потреб і збереження здоров'я (при цьому органи охорони та підрозділи Державної прикордонної служби України, які безпосередньо здійснюють охорону державного кордону України, мають забезпечуватися усіма видами матеріальних засобів найкращої якості та в першу чергу);

забезпечення правильної експлуатації, зберігання та ремонту озброєння, бойової та іншої техніки та майна;

експлуатацію і ремонт казармено-житлового фонду, комунальних споруд, а також під’їзиих шляхів;

організацію протипожежної охорони органів і підрозділів охорони кордону;

ведення діловодства, обліку і звітності з усіх видів матеріальних засобів та інших питань забезпечення діяльності органу та підрозділу охорони кордону; порядок пред’явлення претензій та вирішення справ щодо нестач і втрат матеріальних засобів.

Висвітлені питання посилюють актуальність їх значення у контексті готовності до їх вирішення офіцерами та військовослужбовцями за контрактом.

Для якісної організації ведення військового (корабельного) господарства в органах (підрозділах) ДПСУ військовослужбовці повинні і зобов'язані володіти грунтовними специфічними знаннями, практичними навичками, фаховими (професійними) вміннями.

Для визначення характеристик необхідного рівня знань, умінь і навичок щодо організації ведення військового (корабельного) господарства здійснено аналіз наукової педагогіко-психологічної літератури, проаналізовано відгуки про курсантів, проведено анкетування 3 офіцерами, що навчаються на факультеті керівних кадрів НАДПСУ, проведено бесіди 3 офіцерами, що виконують обов'язки начальників служб матеріально-технічного забезпечення, заступників начальників відділу прикордонної служби з логістики, начальників відділів прикордонної служби, офіцерами внутрішньої та власної безпеки, офіцерами які перебували на курсах підвищення кваліфікації, а також - 3 викладацьким складом НАДПСУ.

За підсумками дослідження і з урахуванням вимог керівних документів [14] нам вдалося отримати практичні поради щодо розв'язання проблемних питань, які існують в органах і підрозділах ДПСУ стосовно ведення військового (корабельного) господарства. Цю інформацію було взято за основу під час визначення критеріїв i показників, а також - характеристики рівнів сформованості професійної готовності майбутніх офіцерів до ведення військового (корабельного) господарства у підрозділах ДПСУ. За підсумками проведених досліджень виокремлено такі критерії: мотиваційний, когнітивний, операційний, прогностичний, морально-вольовий. Саме такі критерії здатні забезпечити необхідний результат у опануванні основних засад організації ведення військового (корабельного) господарства у підрозділах ДПСУ. 
Розглянемо визначені нами критерії та показники готовності майбутніх офіцерів до ведення військового (корабельного) господарства підрозділів ДПСУ більш детально.

Мотиваційний критерій виступає домінантою в процесі реалізації професійної готовності майбутніх офіцерів до організації ведення військового (корабельного) господарської та передбачає формування позитивних професійних мотивів, інтересів, установок, позитивного ставлення до оволодіння спеціальними знаннями та компетенціями щодо організації ведення військового (корабельного) господарства в підрозділах ДПСУ. Тільки сформоване прагнення та об'єктивна зацікавленість господарською діяльністю підрозділів прикордонної служби буде мобілізувати особистість до набуття високого рівня професійної майстерності та дасть можливість сформувати чітке уявлення щодо їі успішності та ефективності, дозволить майбутнім офіцерам ефективно організовувати та здійснювати супровід господарської діяльності. Показниками мотиваційного критерію визначені: наявність стійкого інтересу майбутніх офіцерів до ведення військового (корабельного) господарства; їхня позитивна мотивація до здійснення професійної діяльності, зокрема організації ведення військового (корабельного) господарства в підрозділах ДПСУ; сформованість ціннісних орієнтацій, притаманних господарнику або господарю.

Когнітивний критерій характеризує пізнавальну основу професійної готовності майбутніх офіцерів до ведення військового (корабельного) господарства в підрозділах ДПСУ і включає в себе систему загально професійних та спеціальних знань. До основних показників когнітивного критерію відносимо: володіння педагогічними, психологічними та професійними знаннями; володіння знаннями щодо організації та ведення військового (корабельного) господарства в підрозділах ДПСУ.

Операційний критерій професійної готовності характеризується системою умінь та здатностей майбутніх офіцерів, необхідних для ефективної організації та ведення військового (корабельного) господарства в підрозділах ДПСУ. Показниками операційного критерію виступають: сформованість вмінь майбутнього офіцера успішно застосовувати необхідні знання, навички, щодо нормування матеріальних засобів; володіння навичками щодо порядку складання звітності; відпрацювання документів щодо прийому, передачі матеріальних засобів; володіти знаннями та вміннями користуватися спеціалізованим програмним забезпеченням 3 метою оптимізації документів обліку, складанні відповідних програм.

Прогностичний критерій готовності характеризує професійну готовність майбутнього офіцера як систему умінь, знань щодо здатності забезпечити одержання упередженої інформації про потреби у матеріально-технічних засобах; провести аналіз, прогноз необхідних даних чи розрахунків; вміти передбачити наслідки за прийняті або не віддані своєчасно рішеннями; здатність спрогнозувати, змоделювати маючі необхідні параметри. Показниками прогностичного критерію виступають: сформовані знання, вміння, навички щодо своєчасного, повного, упереджуючого аналізу, прогнозу 
стану справ щодо організації ведення військового (корабельного) господарства в підрозділі ДПСУ.

Морально-вольовий критерій характеризується сформованістю професійно важливих якостей майбутніх офіцерів таких як совість, чесність, гідність, воля формувати чесне, відкрите, справедливе, гідне керівництво роботою щодо забезпечення якісної організації ведення військового (корабельного) господарства у підрозділах ДПСУ. Показниками моральновольового критерію виступають сформованість у майбутніх офіцерів комунікативної толерантності, емпатії, комунікативних здібностей, лідерських та вольових якостей, готовності до колективної взаємодії та зближення 3 людьми.

Визначені в дослідженні показники і критерії професійної готовності майбутніх офіцерів до ведення військового (корабельного) господарства у підрозділах ДПСУ взаємопов'язані, взаємозумовлені та становлять цілісне утворення, яке буде виступати певним ідеальним стандартом, що дозволяють схарактеризувати відповідні рівні готовності. За результатами аналізу різних значень терміна «рівень» зроблено висновок, що у нашому дослідженні рівень це ступінь якості, величина, досягнута у готовності майбутніх офіцерів до ведення військового (корабельного) господарства у підрозділах ДПСУ.

Сучасні дослідники професійних якостей прикордонників виділяють наступні рівні професійної готовності. У дослідженнях, проведених О. Войцехівським, пропонується враховувати вимоги Болонського процесу щодо застосування шкали оцінювання ESTS, яка передбачає сім рівнів. Але для узагальнення результатів дослідження i порівняння, а також ураховуючи кількість рівнів підготовки, що встановлювались іншими дослідниками, він зводить їх кількість до чотирьох: високий, середній, задовільний, низький [2].

Зокрема, О. Гнидюк у своєму дослідженні визначив такі рівні: низький, допустимий, середній, оптимальний [5].

А. Чудик виокремив оптимальний, середній, недостатній рівні сформованості готовності майбутніх офіцерів-прикордонників до застосування спеціальних засобів [7].

Для розподілу ступеня сформованості професійної готовності майбутніх офіцерів до ведення військового (корабельного) господарства у підрозділах ДПСУ за відповідними рівнями ми врахували вищеописаний досвід [2], [5], [7] думку офіцерів, які мають значний практичний досвід проходження служби у підрозділах ДПСУ (від 5 до 15 років) і у своїй діяльності вирішують питання, пов'язані 3 організацією ведення військового (корабельного) господарства, а також офіцерів-викладачів, які мають досвід викладацької діяльності не менше 5 років. У результаті ми дійшли висновку, що для характеристики якості сформованих знань, умінь і навичок нам потрібно виокремити головні (базові) вимоги, які сформують i нададуть можливість майбутньому офіцеру організувати ведення військового (корабельного) господарства.

Такими значущими вимогами стали.

1. Розуміти, що таке військове (корабельне) господарство підрозділу ДПСУ. 
2. Знати й розуміти головну мету військового (корабельного) господарства.

3. Вміти організувати та здійснювати керування військовим (корабельним) господарством у підрозділі.

4. Знати які заходи включає організація та ведення військового (корабельного) господарства.

5. Знати що входить до об'єктів військового (корабельного) господарства.

6. Знати порядок утримання об'єктів військового (корабельного) господарства.

7. Знати обов'язки посадових осіб, що відають військовим та корабельним господарством у підрозділах ДПСУ.

8. Знати нормування матеріальних засобів.

9. Знати порядок витребування, зберігання, видачі матеріальних засобів.

10. Вміти складати (перевіряти) звітності.

11. Вміти проводити перевірки, інвентаризацію матеріально-технічних засобів що знаходяться у підрозділі.

12. Розумітися для чого призначений облік матеріальних засобів, знати порядок ведення обліку матеріальних засобів у підрозділу.

13. Вміти організувати підготовку казармено-житлового фонду до осіннєзимового та весняно-літнього періоду експлуатації.

14. Знати особливості ведення корабельного, авіаційного господарства у підрозділу ДПСУ.

Результат сформованих вимог, здатний забезпечити відповідні знання, уміння, навички і дозволить сформувати наступну шкалу рівнів сформованості та розкрити сутність кожного рівня:

Достатній рівень професійної готовності майбутніх офіцерів до організації ведення військового (корабельного) господарства у підрозділах ДПСУ характеризується: позитивним ставленням до здійснення професійної діяльності; ціннісним ставленням до організації господарської діяльності; високим рівнем умотивованості до питань господарської діяльності; грунтовними загально професійними та спеціальними знаннями; сформованими вміннями, навичками та досвідом організації ведення військового (корабельного) господарства у підрозділах ДПСУ; здатністю планувати, залучати, супроводжувати, аналізувати та вносити зміни у власну професійну діяльність із урахуванням специфіки військового (корабельного) господарства підрозділу ДПСУ; сформованістю комунікативної толерантності, емпатії, готовності до колективної взаємодії, організаторських та лідерських якостей; високим рівнем рефлективності та постійним прагненням до самовдосконалення.

Середній рівень професійної готовності майбутніх офіцерів до організації ведення військового (корабельного) господарства у підрозділах ДПСУ характеризується: ситуативним ставленням майбутніх офіцерів до організації ведення військового (корабельного) господарства у підрозділах ДПСУ, спричиненим зміною мотивів у залежності від зовнішніх впливів; неповним 
усвідомленням значущості організації ведення військового (корабельного) господарства підрозділу ДПСУ; наявністю частково систематизованих загально професійних знань та епізодичних спеціальних знань щодо особливостей організації ведення військового (корабельного) господарства у підрозділах ДПСУ; фрагментарно розвиненими вміннями щодо організації, продуктивної взаємодії, планування, супроводу, аналізу та корегування організації ведення військового (корабельного) господарства у підрозділах ДПСУ; недостатньою розвиненістю комунікативної толерантності, емпатії, готовності до колективної взаємодії, організаторських та лідерських якостей; обмеженою здатністю та нестабільністю до здійснення самоаналізу, самоконтролю та самооцінки щодо сформованості власної готовності до організації ведення військового (корабельного) господарства у підрозділах ДПСУ.

Недостатній рівень готовності майбутніх офіцерів до ведення військового (корабельного) господарства у підрозділах ДПСУ характеризується: відсутністю інтересу до професійної діяльності, зокрема, до господарської діяльності; недостатньо сформованим бажанням працювати за відповідним напрямом діяльності; поверхневістю, нестійкістю та несистематизованістю професійно важливих знань; недостатньою обізнаністю зі змістом, методами та способами організації ведення військового (корабельного) господарства у підрозділах ДПСУ; недостатньою сформованістю професійно важливих якостей; обмеженою здатністю або відсутністю вміння організовувати ведення військового (корабельного) господарства у підрозділах ДПСУ, налагоджувати взаємодію; низьким рівнем розвитку емпатії та комунікативної толерантності; несформованістю організаторських та лідерських якостей; нездатністю до рефлексивних дій; неготовністю нести відповідальність за результати виконаної роботи.

У цифровому вираженні це можливо зобразити через оцінки від 1 до 5 , де оцінка від 3,51 до 5,00 визначає достатній рівень; оцінка від 2,50 до 3,50 середній рівень; оцінка від 1,00 до 2,49 недостатній рівень. Визначення рівня професійної готовності до ведення військового (корабельного) господарства у підрозділах ДПСУ подано у таблиці 2.

Таблиця 2

Визначення рівня сформованості професійної готовності до організації
ведення військового (корабельного) господарства у підрозділах ДПСУ

\begin{tabular}{|c|c|}
\hline Оцінка & $\begin{array}{c}\text { Рівень сформованості } \\
\text { готовності }\end{array}$ \\
\hline $3,51 \div 5,00$ & ДОСТАТНІЙ \\
\hline $2,50 \div 3,50$ & СЕРЕДНІЙ \\
\hline $1,00 \div 2,49$ & НЕДОСТАТНИИ \\
\hline
\end{tabular}

Стосовно рівнів сформованості професійної готовності до організації ведення військового (корабельного) господарства у підрозділах ДПСУ чому саме три, i чому саме такі рівні. Ми розуміємо, що для опанування 
анонсованого питання майбутнім офіцерам не потрібні фундаментальні знання. Ïх можливо досягнути за допомогою відповідно розроблених методів та методик, що ї $є$ ціллю нашої роботи. Відповідно ми обмежуємося простими i зручним рівнями сформованості, це достатній, середній, недостатній. Рахуємо що для додаткової професійної готовності цього достатньо.

Отже, результати аналізу наукової літератури, дослідження поважних науковців [1], [2], [3], [4], [5], [6], [7] отримані результати наших досліджень дозволили визначити основні критерії та показники сформованості професійної готовності майбутніх офіцерів до ведення військового (корабельного) господарства у підрозділах ДПСУ, а на основі розроблених критеріїв i показників - виділити три рівні іï сформованості.

Розроблену у нашому дослідженні систему критеріїв, показників і рівнів у подальшому можна використовувати в експериментальній роботі.

Висновки та перспективи подальших досліджень. Таким чином, сукупність проаналізованих теоретико-методологічних підходів дозволить всебічно дослідити проблему професійної готовності майбутніх офіцерів до ведення військового (корабельного) господарства у підрозділах ДПСУ, іiі структуру.

У контексті розв'язання проблеми професійної готовності майбутніх офіцерів до ведення військового (корабельного) господарства у підрозділах ДПСУ актуальними є питання впровадження в освітній процес Національної академії окремої дисципліни «Організація ведення військового (корабельного) господарства у підрозділах ДПСУ», що забезпечить розвиток фахової компоненти за спеціальностями «252 Безпека державного кордону», «274 Автомобільний транспорт», «053 Психологія», «172 Телекомунікації та радіотехніка», «035 Філологія». Разом 3 тим необхідно підкреслити, що випускники Національної академії для подальшого проходження служби розподіляються у авіаційні та морські підрозділи охорони кордону із специфічними питаннями організації ведення військового (корабельного) господарства. Відповідно постає питання щодо їх обізнаності у питаннях організації ведення військового (корабельного) господарства у підрозділах ДПСУ. Вирішення даного питання можливо за рахунок курсів підвищення кваліфікації, для цього необхідно відпрацювати спеціальні програми, тематичні плани вивчення окремих складових організації ведення військового (корабельного) господарства у авіаційних та морських підрозділах охорони кордону ДПСУ.

\section{ЛIТЕРАТУРА}

1. Балагур Л.О. Підготовка майбутніх офіцерів-прикордонників до управління основними підрозділами охорони державного кордону : дис. ... канд. пед. наук : 13.00.04 «Теорія і методика професійної освіти». Хмельницький , 2015. 227 с.

2. Войцехівський О.Л. Підготовка майбутніх офіцерів-прикордонників до професійної діяльності в пунктах пропуску через державний кордон : дис. ... канд. пед. наук : 13.00.04 «Теорія і методика професійної освіти». Хмельницький, 2012. 252 с. 
3. Гащук В.А. Педагогічні умови деонтологічної підготовки майбутніх офіцерівприкордонників : дис. ... канд. пед. наук : 13.00.04 «Теорія і методика професійної освіти». Хмельницький, 2016. 233 с.

4. Гнидюк О.Я. Підготовка майбутніх офіцерів-прикордонників до роботи 3 нанесення контрольованих прикордонних районів: дис. ... канд. пед. наук : 13.00.04«Теорія і методика професійної освіти». Хмельницький, 2013. 206 с.

5. Гнидюк О.П. Педагогічні умови підготовка майбутніх офіцерів-прикордонників до фізичного самовдосконалення : дис. ... канд. пед. наук : 13.00 .04 «Теорія і методика професійної освіти». Хмельницький, 2015. 236 с.

6. Заболотна О.Р. Підготовка майбутніх офіцерів-прикордонників до роботи 3 технічними засобами прикордонного контролю : дис. ...канд. пед. наук : 13.00.04«Теорія і методика професійної освіти». Хмельницький, 2012. 229 с

7. Чудик А.В. Підготовка майбутніх офіцерів-прикордонників до застосування спеціальних засобів та заходів фізичного впливу у процесі оперативно-службової діяльності : дис. ... канд. пед. наук : 13.00 .04 «Теорія і методика професійної освіти». Хмельницький, 2015. 223 c.

8. Карпенчук С.Г. Теорія і методика виховання: Навчальний посібник. Київ : Вища школа, 1997. 304 с.

9. Гончаренко С. Український педагогічний словник. Київ : Либідь, 1997. 376 с.

10. Костенко В.А. Критерії та показники професійної компетентності молодого інспектора відділу нагляду і безпеки кримінально-виконавчих установ. Збірник наукових праць Національної академії Державної прикордонної служби. Хмельницький : НАДПСУ, 2007. №41/2. С. 111-114.

11. Новий тлумачний словник української мови. Том 3 (П-Я) / Уклад. В.В. Яременко, О.М. Сліпушко. Київ : Акотін, 2001. 927 с.

12. Короткий тлумачний словник української мови (Уклад.: Д.Г. Гринчишин, Л.Л. Гумецька, В.Л. Карпова та інші; Відп. Ред. Л.Л. Гумецька). Київ : Рад. Школа, 1978. 296 c.

13. Івченко А. Тлумачний словник української мови / Худож.-оформлювач С.А. Пятковка. Харків : Фоліо, 2001. 540 с.

14. Про затвердження Порадника 3 військового (корабельного) господарства Державної прикордонної служби України : наказ Адміністрації Державної прикордонної служби України від 21 грудня 2020 року №134. 42 с.

15. Саган В.В. Сутність, особливості змісту і структура поняття «професійна готовність офіцера прикордонника до ведення військового (корабельного) господарства». Збірник наукових праць Національної академії Державної прикордонної служби. Хмельницький : НАДПСУ, 2021, №1. С.283-298.

16. Саган В.В. Професійна готовність офіцера прикордонника до ведення господарської діяльності прикордонного підрозділу як педагогічна проблема. Збірник наукових праць Національної академії Державної прикордонної служби. Хмельницький : НАДПСУ, 2020, №4 (23). С.291-306.

\section{REFERENCES}

1. Balahur, L. O. (2015). Pidhotovka maibutnikh ofitseriv-prykordonnykiv do upravlinnia osnovnymy pidrozdilamy okhorony derzhavnoho kordonu [Training of future border guard officers to manage the basic units of state border protection]. PhD Thesis in Pedagogics. Khmelnytskyi.

2. Voitsekhivskyi, O. L. (2012). Pidhotovka maibutnikh ofitseriv-prykordonnykiv do profesiinoi diialnosti $\mathrm{v}$ punktakh propusku cherez derzhavnyi kordon [Training of future border guard officers for professional activities at border crossing points]. PhD Thesis in Prdagogics. Khmelnytskyi. 
3. Hashchuk, V. A. (2016). Pedahohichni umovy deontolohichnoi pidhotovky maibutnikh ofitseriv-prykordonnykiv [Pedagogical conditions of deontological training of future border guard officers]. PhD Thesis in Pedagogics. Khmelnytskyi.

4. Hnydiuk, O. Ya. (2013). Pidhotovka maibutnikh ofitseriv-prykordonnykiv do roboty z nanesennia kontrolovanykh prykordonnykh raioniv [Training of future border guard officers for work on the application of controlled border areas]. PhD Thesis in Pedagogics. Khmelnytskyi.

5. Hnydiuk, O. P. (2015). Pedahohichni umovy pidhotovka maibutnikh ofitserivprykordonnykiv do fizychnoho samovdoskonalennia [Pedagogical conditions for preparation of future border guard officers for physical self-improvement]. PhD Thesis in Pedagogics. Khmelnytskyi.

6. Zabolotna, O. R. (2012). Pidhotovka maibutnikh ofitseriv-prykordonnykiv do roboty z tekhnichnymy zasobamy prykordonnoho kontroliu [Training of future border guard officers to work with technical means of border control]. PhD Thesis in Pedagogics. Khmelnytskyi.

7. Chudyk, A. V. (2015). Pidhotovka maibutnikh ofitseriv-prykordonnykiv do zastosuvannia spetsialnykh zasobiv ta zakhodiv fizychnoho vplyvu u protsesi operatyvnosluzhbovoi diialnosti [Training of future border guard officers for the use of special means and measures of physical influence in the process of operational and service activities]. PhD Thesis in Pedagogics. Khmelnytskyi.

8. Karpenchuk, S. H. (1997). Teoriia i metodyka vykhovannia: Navchalnyi posibnyk [Theory and methods of education: Textbook]. Kyiv: Vyshcha shkola.

9. Honcharenko, S. (1997). Ukrainskyi pedahohichnyi slovnyk [Ukrainian pedagogical dictionary]. Kyiv: Lybid.

10. Kostenko, V. A. (2007). Kryterii ta pokaznyky profesiinoi kompetentnosti molodoho inspektora viddilu nahliadu i bezpeky kryminalno-vykonavchykh ustanov [Criteria and indicators of professional competence of young inspectors of the supervision and security department of penitentiary institutions]. Zbirnyk naukovykh prats Natsionalnoi akademii Derzhavnoi prykordonnoi sluzhby. Khmelnytskyi: NADPSU, 41/2, 111-114.

11. Yaremenko, V. V. \& Slipushko, O. M. (2001). Novyi tlumachnyi slovnyk ukrainskoi movy [New explanatory dictionary of the Ukrainian language]. Tom 3 (P-Ya). Kyiv: Akotin.

12. Hrynchyshyn, D. H., Humetska, L. L., Karpova, V. L. et al; Ed. Humetska, L. L. (1978). Korotkyi tlumachnyi slovnyk ukrainskoi movy [Brief explanatory dictionary of the Ukrainian language]. Kyiv: Rad. Shkola.

13. Ivchenko, A. (2001). Tlumachnyi slovnyk ukrainskoi movy [Explanatory dictionary of the Ukrainian language] / Artistic design by Piatkovka, S. A. Kharkiv: Folio.

14. Pro zatverdzhennia Poradnyka z viiskovoho (korabelnoho) hospodarstva Derzhavnoi prykordonnoi sluzhby Ukrainy : nakaz Administratsii Derzhavnoi prykordonnoi sluzhby Ukrainy vid 21 hrudnia 2020 roku №134 [On approval of the Guidelines on Military (Ship) Economy of the State Border Guard Service of Ukraine: Order of the Administration of the State Border Guard Service of Ukraine of December 21, 2020].

15. Sahan, V. V. (2021). Sutnist, osoblyvosti zmistu i struktura poniattia «profesiina hotovnist ofitsera prykordonnyka do vedennia viiskovoho (korabelnoho) hospodarstva» [The essence, features of content and structure of the concept "professional readiness of a border guard officer to manage military (ship) economy"]. Zbirnyk naukovykh prats Natsionalnoi akademii Derzhavnoi prykordonnoi sluzhby. Khmelnytskyi: NADPSU, 1, 283-298.

16. Sahan, V. V. (2020). Profesiina hotovnist ofitsera prykordonnyka do vedennia hospodarskoi diialnosti prykordonnoho pidrozdilu yak pedahohichna problema [Professional readiness of a border guard officer to manage economic activities of a border guard unit as a pedagogical problem]. Zbirnyk naukovykh prats Natsionalnoi akademii Derzhavnoi prykordonnoi sluzhby. Khmelnytskyi: NADPSU, 4 (23), 291-306. 
РЕЗЮМЕ

Виталий Саган

Национальная академия Государстенной пограничьной службы Украины имени Богдана Хмельницкого

\section{Критерии, показатели и уровни сформирования профессиональной готовности будущих офицеров к ведению военного (корабельного) хозяйства в подразделениях Государственной пограничной службы Украины}

В статье проведен анализ научной литературы и освещены взгляды относительно критериев, показателей и уровней сформированной профессиональной готовности будущих офииеров к ведению войскового (корабельного) хозяйства в подразделениях Государственной пограничной службы Украины (далее - ГНСУ).

В проиессе исследования пришли $\kappa$ выводу, что изучать готовность нужно соответственно к конкретному виду деятельности, учитывая общие, унифицированные для любой профессиональной деятельности компоненты и специфические профессиональные компоненты готовности, которые присущи определенному виду деятельности.

Ключевые слова: военная (корабельном) хозяйстве, критерии, показатели, уровни, профессиональная готовность.

\section{SUMMARY}

Vitalii Sahan, senior instructor at the Logistics Department of the Bohdan Khmelnytskyi National Academy of the State Border Guard Service of Ukraine, Khmelnytskyi

\section{Criteria, Indicators and Levels of Professional Readiness Formation of Future Officers to Management of Military (Ship) Economy in Units of State Border Guard Service of Ukraine}

Introduction. The regulatory documents of the Administration of the State Border Guard Service of Ukraine stipulate that officials of bodies and units of the State Border Guard Service of Ukraine (SBGS) who organize and manage military (ship) economy are responsible for this economy and perform their duties in accordance with the Law of Ukraine "On Internal Service Regulations of the Armed Forces of Ukraine".

But the curricula of the Bohdan Khmelnytskyi National Academy of the State Border Guard Service of Ukraine do not provide for academic disciplines that should provide future officers with the necessary knowledge, skills, abilities to organize military (ship) economy in the SBGS units.

The purpose of the article is to develop criteria, indicators and formation levels of professional readiness of future officers for managing military and ship economy in SBGS units.

The methods of observation, sociological survey, testing, analysis and synthesis were used to study the announced topic.

The results of the analysis allowed to determine the main criteria and indicators of the professional readiness formation of future officers to manage military (ship) economy in the SBGS units, and to identify three levels of its formation on the basis of the developed criteria and indicators.

Originality and practical importance of the research. The issues of research on the organization of military (ship) economy in the units of the State Border Guard Service are raised for the first time. The criteria, indicators and formation levels of professional readiness of future officers for managing military (ship) economy in units of the State Border Guard Service of 
Ukraine are researched for the first time. The system of criteria, indicators and levels developed in our research can be further used in experimental work.

Conclusion and prospects for further research. Thus, the set of analysed theoretical and methodological approaches will allow to comprehensively research the problem of professional readiness of future officers to manage military (ship) economy in the SBGS units and its structure.

In the context of solving the problem of professional readiness of future officers to manage military (ship) economy in SBGS units, the issues of substantiation of pedagogical conditions and development of structural and functional model for training future officers for managing military (ship) economy in SBGS units are relevant.

Keywords: military (ship) economy, criteria, indicators, levels, professional readiness. 